\title{
Physiological Effects of Spirulina platensis in Salt Stressed Vicia faba L. Plants
}

\author{
Eman El-Sayed Selem
}

Department of Botany, Faculty of Science, Zagazig University, Zagazig, Egypt.

\begin{abstract}
QALINITY is one of the most important problems in Egypt. Soil salinity decreases growth, photosynthetic activity, and results in nutrient imbalance in plants. This study evaluated the efficacy of the foliar applied Spirulina platensis $(100 \mathrm{mg} / \mathrm{L})$ in reducing salinity effects in Vicia faba $\mathrm{L}$. plants. The treatments are, $\mathrm{T}_{1}$ (control), $\mathrm{T}_{2}$ (salinity, $135 \mathrm{mM}$ from $\mathrm{NaCl}$, equivalent to $13 \mathrm{dS} \mathrm{m}^{-1}$ ), $\mathrm{T}_{3}$ (Spirulina platensis, $100 \mathrm{mg} / \mathrm{L}$ ), and $\mathrm{T}_{4}$ (salinity, $135 \mathrm{mM}^{+}$Spirulina platensis, $100 \mathrm{mg} / \mathrm{L})$. Salinity decreased significantly chlorophyll $a+b$, carotenoids, weights of 100 seed, photosynthetic activity $\left({ }^{14} \mathrm{CO}_{2}\right.$ fixation), transpiration rate , total protein and $(\mathrm{N}, \mathrm{P}$ and $\mathrm{K})$. Application of $\mathrm{T}_{4}$ improved the above parameters as compared to salt-stressed plants. Salinity increased significantly the SOD, POD, CAT, GPX, MDA, free proline, total phenol and $\mathrm{Na}^{+}$and $\mathrm{Cl}^{-}$as compared to the control plants. However, $\mathrm{T}_{4}$ treatment decreased the activity of the above parameters as compared to salt-stressed plants. Foliar applied Spirulina platensis ameliorated adverse effects of salinity by enhancing total protein level, N, P and K and photosynthetic activity $\left({ }^{14} \mathrm{CO}_{2}\right.$ assimilation). This first attempt to evaluate the potential of Spirulina platensis as growth enhancer under salt-stressed Vicia faba indicated that exogenously applied Spirulina platensis $(100 \mathrm{mg} / \mathrm{L})$ provided more benefit against salinity stress.
\end{abstract}

Keywords: Vicia faba L., Photosynthetic activity $\left({ }^{14} \mathrm{CO}_{2}\right.$ fixation), Spirulina platensis, Salt stress.

\section{Introduction}

Faba bean (Vicia faba L.) is one of the most important crops used for food, animal feed and industry (Moussa, 2008).

Salinity in the soil causes limitation in the plant growth, productivity particularly in arid and semi-arid areas (Shannon, 1998). Additionally, salinity leads to increase in respiratory rate, ion toxicity, alteration of plant growth, imbalance in the distribution of elements, instability of membranes as a result of replacing the sodium element instead of calcium (Marschner, 1986). However, salinity decreases the photosynthetic rate (Moussa et al., 2016). It is well known that the accumulation of sodium ions in leaf tissues causes a decrease in the enzymatic activities and protein synthesis which is strongly related to high concentrations of salinity (Tester \& Davenport, 2003). The external addition of some plant growth regulators, osmoprotectants and fertilizers reduces the damages resulting from salt stress (Ashraf et al., 2008). Successful attempts used algae as a biofertilizer in the process of soil reclamation, such as alkali and calcareous soil (Hegde et al., 1999).
Spirulina platensis is one of the photosynthetic blue-green microalga. Nowadays it is produced commercially as a food source, animal feed and bio-fertilizer with high nutritional value (Sànchez et al., 2003). S. platensis has been used as biofertilizer for many crops in different application methods individually or combined with other organic fertilizers (Aly et al., 2008). Ali \& Mostafa (2009) tested the effect of spraying or using soil application methods of potassiumhumate and $S$. platensis, either individually or in combination and used both as a bio- organic fertilizer on sesame plant. They found that the combined foliar application showed the highest rates in plant height, number of capsules per plant, number of branches per plant, seed weight per plant and weight of one thousand seeds. While, combined soil application showed the highest yield and production of seeds and straw. Therefore, the use of cyanobacteria species as a biofertilizers has been recommended rather than the use of high-cost chemical ones. This is due to the fact that this chemical fertilizers cause pollution of soil and water. Spirulina biomass consists of about $62 \%$ amino acids and it contains also the whole spectrum of mixed natural carotene and xanthophyl phytopigments which 
are considered as a rich natural source of vitamin B-12 and antioxidants (Kemka et al., 2007). The cyanbacterium Spirulina is considered to be ideal dietary supplements and one of the best solutions for treating malnutrition problems in developing countries (Vendan \& Rajeshwari, 1998)

The goal of this study was to demonstrate whether it is possible to use exogenous application of $S$. platensis to mitigate the harmful effects of salinity in faba bean plants.

\section{Materials and Methods}

\section{Plant material and seedlings formation}

Faba bean seeds cv. Giza 2 were purchased from the Crop Institute, Agriculture Research Center, Giza, Egypt. The seeds were surface sterilized by $0.1 \%(\mathrm{w} / \mathrm{v})$ sodium dodecyl sulfate solution and rinsed with sterile deionized water. They were germinated in pots $(40 \times 35 \mathrm{~cm}$, height $\times$ diameter), filled with $10 \mathrm{~kg}$ of a sandy loam soil with $2.5 \%$ organic matter and available $\mathrm{N}$, $\mathrm{P}$, and $\mathrm{K}$ concentrations of 170,80 and $200 \mathrm{mg}$ $\mathrm{kg}^{-1}$, respectively. Irrigation with $250 \mathrm{ml}$ of the Hoagland's nutrient solution (Hoagland \& Arnon, 1950) was supplied to each pot every 5 days. Plants were grown in a controlled environment growth chamber with a $15 \mathrm{~h}$ photoperiod; $65 \%-75 \%$ relative humidity; and day and night temperatures of 22 and $20^{\circ} \mathrm{C}$. The maximum photosynthetic photon flux density at the plant canopy was $\sim 440 \mu \mathrm{M} \mathrm{m}^{-2} \mathrm{~s}^{-1}$. Ten days after emergence plants were thinned to four seedlings per pot.

\section{Salt stress experiment}

The experimental design was a randomized complete block design with three replications. Salt stress was imposed at 20 days after seedling emergence.

Seedlings were irrigated with a full Hoagland solution containing either 0.0 (water-only control) or $135 \mathrm{mM} \mathrm{NaCl}$, equivalent to $13 \mathrm{dS} \mathrm{m} \mathrm{m}^{-1}$. The treatments are, $\mathrm{T}_{1}$ (control), $\mathrm{T}_{2}$ (salinity, $135 \mathrm{mM}$ ), $\mathrm{T}_{3}$ (S. platensis, $100 \mathrm{mg} / \mathrm{L}$ ), and $\mathrm{T}_{4}$ (salinity, 135 $\mathrm{NaCl} \mathrm{mM}+$ Spirulina platensis, $100 \mathrm{mg} / \mathrm{L})$. Pots were rinsed with $400 \mathrm{ml}$ of distilled water once weekly to avoid salt accumulation. The $S$. platensis $(100 \mathrm{mg} / \mathrm{L})$ were added to Tween 20 to fix solutions to plant leaf surfaces. Solutions were applied once onto leaves in the morning at flowering stage (plants that are 50 days old) using a manual pump. All determinations were carried out at 65-day-old plant except, weights of 100 seed were determined at the harvest stage.

\section{Chemical analysis}

Pigment content was determined according to Inskeep \& Bloom (1985). Transpiration rate was determined as described by Ludlow \& Muchow (1990). Proline was determined according to Bates et al. (1973). Total protein content was quantified according to Bradford (1976). Malondialdehyde (MDA) content was determined as described by Chen et al. (2013). Total phenol content was estimated by the method described by Sadasivam \& Manickam (2008).

\section{Photosynthetic activity $\left({ }^{14} \mathrm{CO}\right.$, fixation)}

Photosynthetic activity was measured in the Radioisotope Department, Atomic Energy Authority, Cairo, Egypt, according to Moussa (2008). One pot from each treatment was placed under a bell jar and ${ }^{14} \mathrm{CO}_{2}$ was generated inside the chamber due to a reaction between $10 \% \mathrm{HCl}$ and $50 \mu \mathrm{Ci}(1.87 \times 106 \mathrm{~Bq}) \mathrm{NaH}^{14} \mathrm{CO}_{3}+100 \mathrm{mg}$ $\mathrm{Na}_{2} \mathrm{CO}_{3}$ as a carrier. The samples were illuminated with a tungsten lamp $\left(\sim 300-350 \mu \mathrm{M} \mathrm{m}^{-2} \mathrm{~s}^{-1}\right)$. After $30 \mathrm{~min}$, leaves were quickly detached from the stem, weighed, and frozen for $5 \mathrm{~min}$ to stop biochemical reactions and then subjected to extraction with $80 \%$ hot ethanol. The ${ }^{14} \mathrm{C}$ was assayed in ethanolic extracts using a Bray cocktail (Bray, 1960) and a liquid scintillation counter (LSC2-Scaler Ratemeter SR7, Nuclear Enterprises, Edinburgh, UK).

\section{Elemental analysis}

Determination of $\mathrm{Na}^{+}, \mathrm{K}^{+}$and $\mathrm{Cl}^{-}$was determined with a flame photometer (Jenway model PFP-7, Chelmsford, Essex, England). The method of Prokopy (1995) was used to estimate phosphorus. Total nitrogen was determined in dry seed using Kjeldahl method (AOAC, 1995).

\section{Enzymes assays}

Peroxidase activity (POD, EC 1.11.1.7) was estimated using the method of Thomas et al. (1981). Superoxide dismutase (SOD, EC 1.15.1.1) and catalase (CAT, EC 1.11.1.6) activities were determined as described by Chance \& Maehly (1995). Glutathione peroxidase (GPX, EC 1.11.1.9) activity was determined as the decrease in absorbance at $340 \mathrm{~nm}$ due to the oxidation of NADPH by the method of Navrot et al. (2007). 
Statistical analysis

Data were analyzed using analysis of variance (SPSS, version 10.0, SPSS Inc., Chicago, Ill.). Means were separated with Duncan's multiple range tests.

\section{Results}

The presence of salinity decreased significantly chlorophyll contents (Chl $a+b)$, carotenoids, weights of one hundred seeds, photosynthetic activity and transpiration rate in Vicia faba plants as shown in Table 1. Application of $\mathrm{T}_{4}$ improved the above parameters as compared to plants grown under salinity.

The presence of salinity decreased significantly Chl $a+b$, carotenoids, weights of seeds, photosynthetic activity and transpiration rate in Vicia faba plants (Table 1). Application of $\mathrm{T}_{4}$ improved the above parameters as compared to salt-stressed plants (Table 1).

The presence of salinity accumulated significantly the antioxidant enzymes (SOD, POD, CAT and GPX), MDA, free amino acid proline and total phenols. While, salinity minimized significantly the total protein content when compared to the non-stressed plants (Table 2). Meanwhile, foliar supplement with $S$. platensis in $\mathrm{T}_{4}$ evoked a pronounced increase in the total protein content in comparison to salt stressed faba bean plants (Table 2). In addition, $\mathrm{T}_{4}$ treatment decreased the activity of the antioxidant enzymes, MDA, free amino acid proline and total phenol as compared to salt stressed plants.

Concerning the elements contents, the presence of salinity increased significantly the sodium and chlorine ions as compared to $\mathrm{T}_{1}$ and $\mathrm{T}_{3}$. Meanwhile, $\mathrm{T}_{4}$ treatment decreased significantly these parameters as compared to $\mathrm{T}_{2}$. Salinity decreased significantly the macronutrients content (nitrogen, phosphorus and potassium) when compared to the control. However, $\mathrm{T}_{4}$ treatment increased the macronutrient content as compared to $\mathrm{T}_{2}$ (Table 3 ).

TABLE 1. Changes in $\mathrm{Chl} a+b$, carotenoids, weight of one hundred seeds, photosynthetic activity and transpiration rate in Vicia faba plants grown with or without sodium chloride and foliar applied $S$. platensis.

\begin{tabular}{|c|c|c|c|c|c|}
\hline Treatment & $\begin{array}{c}\mathrm{Chl}(a+b) \\
\left(\mathrm{mg} \mathrm{g}^{-1} \mathrm{FW}\right)\end{array}$ & $\begin{array}{l}\text { Carotenoids } \\
\left(\mathrm{mg} \mathrm{g}^{-1} \mathrm{FW}\right)\end{array}$ & $\begin{array}{c}\text { Wt. of one } \\
\text { hundred seeds } \\
\text { (g) }\end{array}$ & $\begin{array}{l}\text { Photosynthetic activity } \\
\left(10^{3} \text { Becquerel } \mathrm{mg}^{1} \mathrm{FW}\right)\end{array}$ & $\begin{array}{l}\text { Transpiration rate } \\
\left(\mathrm{mM} \mathrm{H_{2 }} \mathrm{O} \mathrm{m}^{-2} \mathbf{s}^{-1}\right)\end{array}$ \\
\hline $\mathrm{T}_{1}$ & $3.68^{b}$ & $1.56^{\mathrm{a}}$ & $65.7^{\mathrm{b}}$ & $15.618^{b}$ & $5.8^{\mathrm{a}}$ \\
\hline $\mathrm{T}_{2}$ & $2.80^{\mathrm{d}}$ & $0.83^{c}$ & $51.6^{\mathrm{d}}$ & $11.803^{\mathrm{d}}$ & $3.0^{\mathrm{b}}$ \\
\hline $\mathrm{T}_{3}$ & $3.78^{\mathrm{a}}$ & $1.58^{\mathrm{a}}$ & $67.8^{\mathrm{a}}$ & $17.599^{\mathrm{a}}$ & $5.7^{\mathrm{a}}$ \\
\hline $\mathrm{T}_{4}$ & $3.47^{\mathrm{c}}$ & $1.32^{\mathrm{b}}$ & $62.7^{\mathrm{c}}$ & $14.601^{\mathrm{c}}$ & $5.0^{\mathrm{c}}$ \\
\hline
\end{tabular}

Data were expressed in triplicates. Data were analyzed statistically by Duncan's test. The different superscripts in the same column are significantly different $(\mathrm{P}<0.01)$.

$\mathrm{T}_{1}$ : Control, $\mathrm{T}_{2}$ : Salinity, $\mathrm{T}_{3}$ : Spirulina platensis and $\mathrm{T}_{4}$ : Salinity + S. platensis .

TABLE 2. Changes in SOD, POD, CAT, GPX, MDA, free amino acid proline, total phenols and total protein in Vicia faba plants grown with or without $\mathrm{NaCl}$ and foliar applied $S$. platensis.

\begin{tabular}{|c|c|c|c|c|c|c|c|c|}
\hline Treatment & $\begin{array}{c}\text { SOD } \\
\text { (units mg }{ }^{-1} \\
\text { protein) }\end{array}$ & $\begin{array}{c}\text { POD } \\
\text { (units mg-1 } \\
\text { protein) }\end{array}$ & $\begin{array}{c}\text { CAT } \\
\left(\mu \mathrm{MH}_{2} \mathrm{O}_{2} / \mathrm{min}\right. \\
\left.\mathrm{gFW}^{2}\right)\end{array}$ & $\begin{array}{c}\text { GPX } \\
(\mu \mathrm{MNADPH} / \mathrm{min} \\
\mathrm{gFW})\end{array}$ & $\begin{array}{c}\text { MDA } \\
\left(\mu \mathbf{M ~ g}^{-1}\right. \\
\text { FW) }\end{array}$ & $\begin{array}{c}\begin{array}{c}\text { Free } \\
\text { proline }\end{array} \\
\left(\mu \mathrm{mol} \mathrm{g} \mathbf{g}^{-1}\right. \\
\text { FW })\end{array}$ & $\begin{array}{c}\text { Total } \\
\text { phenol } \\
\left(\mathbf{m g ~ g}^{-1}\right. \\
\text { DW) }\end{array}$ & $\begin{array}{c}\text { Total } \\
\text { protein } \\
\left(\mathbf{m g ~ g ^ { - 1 }}\right. \\
\text { FW) }\end{array}$ \\
\hline $\mathrm{T}_{1}$ & $7.5^{\mathrm{c}}$ & $11.5^{\mathrm{b}}$ & $3.3^{\mathrm{b}}$ & $8.7^{\mathrm{b}}$ & $2.1^{\mathrm{c}}$ & $310^{\mathrm{c}}$ & $28^{\mathrm{b}}$ & $152^{b}$ \\
\hline $\mathrm{T}_{2}$ & $10.0^{\mathrm{a}}$ & $17.9^{\mathrm{a}}$ & $7.1^{\mathrm{a}}$ & $10.9^{\mathrm{a}}$ & $5.8^{\mathrm{a}}$ & $517^{\mathrm{a}}$ & $33^{\mathrm{a}}$ & $95^{\mathrm{d}}$ \\
\hline $\mathrm{T}_{3}$ & $8.1^{\mathrm{b}}$ & $11.7^{\mathrm{b}}$ & $3.2^{\mathrm{b}}$ & $8.4^{\mathrm{b}}$ & $2.0^{c}$ & $308^{\mathrm{d}}$ & $28^{\mathrm{b}}$ & $168^{\mathrm{a}}$ \\
\hline $\mathrm{T}_{4}$ & $7.4^{\mathrm{c}}$ & $10.9^{\mathrm{c}}$ & $3.0^{\mathrm{c}}$ & $7.9^{\mathrm{c}}$ & $2.7^{\mathrm{b}}$ & $348^{\mathrm{b}}$ & $29^{c}$ & $142^{\mathrm{c}}$ \\
\hline
\end{tabular}

Data were expressed in triplicates. Data were analyzed statistically by Duncan's test. The different superscripts in the same column are significantly different $(\mathrm{P}<0.01)$.

$\mathrm{T}_{1}$ : Control, $\mathrm{T}_{2}$ : Salinity, $\mathrm{T}_{3}$ : Spirulina platensis and $\mathrm{T}_{4}$ : Salinity + S. platensis. 
TABLE 3. Contents of sodium, chloride, nitrogen, phosphorus and potassium in Vicia faba plants grown with or without $\mathrm{NaCl}$ and foliar applied $S$. platensis.

\begin{tabular}{lccccc}
\hline Treatment & Sodium & Chloride & Nitrogen & Phosphorus & Potassium \\
& & & $\left(\mathbf{m g ~ g ^ { - 1 } \mathbf { D W } )}\right.$ \\
\hline $\mathrm{T}_{1}$ & $85^{\mathrm{c}}$ & $250^{\mathrm{c}}$ & $108^{\mathrm{a}}$ & $66^{\mathrm{a}}$ & $55^{\mathrm{a}}$ \\
$\mathrm{T}_{2}$ & $138^{\mathrm{a}}$ & $312^{\mathrm{a}}$ & $86^{\mathrm{d}}$ & $40^{\mathrm{d}}$ & $27^{\mathrm{d}}$ \\
$\mathrm{T}_{3}$ & $82^{\mathrm{c}}$ & $257^{\mathrm{c}}$ & $104^{\mathrm{b}}$ & $62^{\mathrm{b}}$ & $51^{\mathrm{b}}$ \\
$\mathrm{T}_{4}$ & $91^{\mathrm{b}}$ & $265^{\mathrm{b}}$ & $100^{\mathrm{c}}$ & $56^{\mathrm{c}}$ & $46^{\mathrm{c}}$ \\
\hline
\end{tabular}

Data were expressed in triplicates. Data were analyzed statistically by Duncan's test. The different superscripts in the same column are significantly different $(\mathrm{P}<0.01)$.

$\mathrm{T}_{1}$ : Control, $\mathrm{T}_{2}$ : Salinity, $\mathrm{T}_{3}$ : Spirulina platensis and $\mathrm{T}_{4}$ : Salinity $+S$. platensis.

\section{Discussion}

The present study was carried out to evaluate the use of Spirulina platensis as a growth enhancer (bio-fertilizer) in the salt-stressed Vicia faba plants. Data showed that, there was a significant decrease in the growth and yield (represented by the weight of one hundred seeds) as a result of salinization. This result corroborates with that of Moussa et al. (2016) who reported that salinity stress led to the production of excess reactive oxygen species (ROS) which induced a defect in different physiological and biological processes and caused oxidative stress, lipid peroxidation and ion toxicity $\left(\mathrm{Na}^{+}\right.$and $\left.\mathrm{Cl}^{-}\right)$, hence it reflected on plant growth and yield. Salt-stress causes a lot of nutritional changes due to the decrease in the absorption and/or stem transportation. This may be a result of the competition between sodium and potassium ions on the binding locations for cell function processes (Moussa \& Hassen, 2017). Such reports are similar to those of Prasanthi \& Vishnuvardhan (2015) and Hemida et al. (2015).

As shown in the present study, considerable changes in the photosynthetic activity, pigments content (Chl $a+b$, carotenoids) and transpiration rate were recorded in salt-stressed bean plants. Such findings are in accord with those of Moussa et al. (2016), who stated that harmful effects of salinization on the photosynthetic activity are a result of the decline in Rubisco activity, pigment content, restriction of carbon dioxide assimilation and probably a minimized transpiration rate. Salinity raised the activity of the 4 assayed antioxidant enzymes (SOD, CAT, POD, GPX), MDA and total phenols in $V$. faba plants indicating that the plants grow under saltstress exert an oxidative defense mechanism to balance the ROS resulted from salinity (Ashraf, 2009 and Kaye et al., 2011).
The recorded rise in the production of antioxidant enzymes and the antioxidant substances (carotenoids and phenols) under the effect of salinity may have a valuable role in scavenging the ROS produced as a result of stress condition (Moussa et al., 2016).

Data showed that there was an increase in the content of proline under salt stress condition which was in a harmony with the results of Jain et al. (2001) and Chen \& Dickman (2005). These authors reported that proline is a carbon and nitrogen source produced by stressed-plants to be used for rapid recovery from stress and for growth since such amino acid plays as a membrane stabilizer and free radical scavenger. As shown in the results, the total protein content was negatively affected in salt-stressed $V$. faba plant. This result is in agreement with those of Merril (1990) and Mahboobe \& Akbar (2013) who found that in many plant species grow under salinity, the protein content deceased as well as protein pattern changes recorded. Decreasing of protein under saline stress may be attributed to salinity that causes physiological disorders due to the elimination of $\mathrm{K}^{+}$ions by roots of plant where $\mathrm{K}^{+}$is the key element in the synthesis of protein. Also, decrease in potassium diminishes the growth and development of plants (Chen et al., 2007). An inhibition in protein synthesis will be continued at long exposure to stress (Caplan et al., 1990).

Regarding the effect of salinity on N, P and K contents, results showed a significant decrease in such macronutrients in the stressed $V$. faba plants. Similar results were recorded by Talei et al. (2012) who noticed a decrease in $\mathrm{N}, \mathrm{P}, \mathrm{K}^{+}, \mathrm{Ca}^{+2}, \mathrm{Mg}^{+2}$ and Mn content at high salinity levels.

At salt-stress conditions, high concentrations of ions compete with nutrients, especially potassium 
ions, leading to a decrease in the levels of this element. With increased exposure to sodium chloride concentrations, the level of sodium ions and chlorine ions increases as well as decreases in the levels of calcium, magnesium and potassium ions in many plants occur (Khan et al., 2003).

Potassium plays a significant role in stimulating the different metabolic process within the plant cell as enzymes activity, photosynthesis, respiration, carbohydrate synthesis, chlorophyll synthesis, balancing the water amounts in plant leaves and regulating the mechanism of closing and opening of stomata as direct result of the stress resistance (El-Defan et al., 1999). As a result of the decrease in the availability of potassium by salinity because of the presence of large concentrations of sodium and chlorine ions in the soil solution, a lot of damage in the nutrition of the plant occurs and therefore the presence of sufficient amounts of potassium element is a necessity for the plant life.

There are several reasons for the decrease in the availability of potassium ions in the presence of sodium chloride, including the antagonism of potassium and sodium ions at the uptake sites in the roots of plants, sodium ions affect the process of transfer of potassium ions to the xylem in the plant or inhibit the process of absorption (Dorudi \& Siadat, 1999; Al-Harbi, 1995 and Heidari \& Jamshid, 2010).

It is clear that salinity works to reduce the accumulation of nitrogen in plants (Garg et al., 1993). This is due to the fact that chloride uptake increases and accumulates under salinity stress in parallel with a decrease in nitrate concentrations in plant stems (Garg \& Gupta, 1997).

Concentration of the phosphorus element is associated with the photosynthetic rate of the plant, but a decrease in such element will decrease the conversion of fixed carbon to starch (Overlach et al., 1993). For this reason, decreasing phosphorus under the effect of salinity will reduce shoot growth. The relationship between phosphorus and salinity is very complex one and there is no clear mechanisms explain the increase, decrease or unchanged absorption rates of phosphorus in most plant species under salt stress conditions (Grattan \& Grieve, 1992). However, it is probably both chloride and sulphate ions in the simulated salt solutions depressed the uptake of PO-34 by plants and its accumulation in fruits (Ullah et al., 1994).

The effect of $S$. platensis foliar spray on $V$. faba plant growth rate is positively evident not only in growing plants under normal conditions but also in the growing plants under salt stress conditions. However, significant differences were recorded between $V$. faba plants treated with $S$. platensis solution and non-treated ones when grown under salt stress condition. The results revealed that the growth and yield of $V$. faba plants treated with $S$. platensis solution were increased compared with each of the controls and those affected by salinity. Enriched organic fertilizers with biofertilizers especially S. platensis were beneficial in improving plant yield (quantitatively and qualitatively rather than application of organic fertilizers alone (Ahmed et al., 2011). This increase could be attributed to the nitrogenase and nitrate reductase activity of algae, its association with plant surface, peptides and amino acids produced in algae filtrate, and some other compounds that stimulate plant growth (Karthikeyan et al., 2007).

In addition, the available form of ammonia necessary for plant growth can be supplied by most cyanobacteria which can fix the atmospheric nitrogen into an available form of ammonia and thus can be used as bio-fertilizer (Vaishampayan et al., 2001).

In the present results, the foliar application of algal extract with the irrigation with $\mathrm{NaCl}$ resulted in a significant improvement in the pigments contents, photosynthetic activity and transpiration rate. This can be attributed to the presence of many growth-stimulating substances produced by cyanobacteria and their ability to form combinations with vascular and non-vascular plants, such substances increased pigment contents and photosynthetic activity (Karthikeyan et al., 2007). Moreover, the ability of $S$. platensis to stimulate plant growth could be explained by the nitrogen fixation ability of this microalga, beside its elevated content of vitamins and hormones (Priyadarshani \& Rath, 2012).

There are several factors affecting the change in the activity of antioxidant enzymes, including the species, the development and metabolic status of the plant and yet the duration and strength of the stress affecting them (Joseph \& Jini, 2010). 
The results strongly suggest that the use of Spirulina platensis foliar spray has reduced the salt stress effect within the plant by changing its physiochemical properties. Thus, the presence of large levels of antioxidant enzymes under the influence of salinity was decreased by using $S$. platensis spray.

There are beneficial reports about the effects of micro-algae extracts on stressed cultivated plants, e.g., Dunaliella salina and Phaeodactylum tricornutum extracts mitigated salt stress during germination process of bell pepper (GuzmánMurillo et al., 2013) due to a significant reduction in superoxide radical production and a lower lipid peroxidation. Water extract of micro-algae Spirulina maxima and Chlorella ellipsoida improve wheat tolerance to salinity and enhanced antioxidant capacity of the whole grains produced by micro-algal- treated plants (Abd El-Baky et al., 2010).

There is a strong correlation between the tolerance of salt stress and the presence of an effective antioxidant system within the plant and therefore resistance to salt stress is closely related to the efficiency of such antioxidant system (Raza et al., 2007). This is because it is known that plants grow under salt stress are trying to build a complex and effective antioxidant system as well as ROSscavenging enzymes such as: SOD, CAT, APX, GPX, and GR (Alscher et al., 1997 and Apel \& Hirt, 2004) to overcome the effects of salinity.

Abd El-Bakyet al. (2008) stated that algal extracts can maintain the activity of enzymes in general and antioxidant ones in particular and also can protect the plant from the impact of oxidative damage and deals directly with ROS. In addition, the authors found that algal extracts can contain bioactive components that act as growth regulators such as auxins and cytokinins, thus reducing the effect of salinity stress on the metabolic activity of wheat plant. They also revealed that there is a reduction in the effect of salinity on the wheat plants after exposure to the algal extracts and such decrease was a result of reducing the levels of sodium ions, while at the same time increases the amounts of photosynthetic pigments. In addition, they explained the existence of a relationship between the improvement by using the algal extracts in wheat plants exposed to salt stress and the increase in antioxidant defense capabilities, which include non-enzymatic and enzymatic antioxidant systems that led to a reduction in the oxidative damage of the biologically active molecules and retention of many physiological processes in wheat plant such as photosynthesis and productivity.

As recorded in the present results, application of $S$. platensis to salt-stressed plants caused an excess in macronutrient $\mathrm{N}, \mathrm{P}$ and $\mathrm{K}$. This may be correlated with the fact that Cyanobacteria increases soil fertility by increasing the levels of available $\mathrm{N}$ and $\mathrm{P}$. This represents an economic point of view providing about $50 \%$ of the necessary doses of nitrogen, phosphorus and potassium (Singh \& Bisoyi, 1989 and Mahmoud et al., 2007).

S. platensis is also attractive for its highly binding ability to many elements (Mosulishvili et al., 2002 and Zheng \& Gao, 2008). In cells exposed to salt stress, an increase in potassium and/or calcium uptake occurs at the expense of sodium absorption, such phenomenon is necessary to maintain the level of potassium/sodium ratio high and thus maintain the life of cells under stress conditions (Ashraf, 2004 and Kavitha et al., 2012).

The external spraying of the plants with $S$. platensis reduced the effects of salinity in the form of reducing the levels of sodium ions and raising the levels of $\mathrm{K}^{+}, \mathrm{N}$ and $\mathrm{P}$. This resulted in maintaining a high level of $\mathrm{K} / \mathrm{Na}$ ratio as compared to the same levels in growing plants under the conditions of salt stress which did not receive any external treatment.

\section{Conclusion}

Cyanobacteria ( $S$. platensis) showed a good potential to improve the growth and yield of $V$. faba plants grown under salt stress by its valuable components that scavenge ROS and alleviate its adverse effects through regulating the metabolic processes in the plant. Therefore, it is recommended to use the foliar spray with $S$. platensis as biofertilizer for salt stressed plants.

\section{References}

Abd El-Baky, H.H., Hussein, M.M. and El-Baroty, G.S. (2008) Algal extracts improve antioxidant defense abilities and salt tolerance of wheat plant irrigated with sea water. Afr. J. Biochem. Res. 2 (7), 151-164. 
Abd El-Baky, H.H., El-Baz, F.K. amd El Baroty, G.S. (2010) Enhancing antioxidant availability in wheat grains from plants grown under seawater stress in response to microalgae extract treatments. J. Sci. Food. Agric. 90, 299-303.

Ahmed, F.F., Asmaa, A., Mansour, A.E.M., Shaaban E.A. and El-Shamaa, M.S. (2011) Response of Thompson seedless grapevines to application of some amino acids enriched with nutrients as well as organic and biofertilization. Res. J. Agric. .Biolo. Sci.7(2), 282286.

Al-Harbi, A.R. (1995) Growth and nutrient composition of tomato and cucumber as affected by sodium chloride salinity and supplemental calcium. J. Plant. Nutrition. 18, 1403-1416.

Ali, Lila K.M. and Mostafa, Soha S.M. (2009) Evaluation of potassium humate and Spirulina platensis as bioorganic fertilizer for sesame plants grown under salinity stress. Egypt. J. Agric. Res. 87(1), 369-388.

Alscher, R.G., Donahue, J.L. and Cramer, C.L. (1997) Reactive oxygen species and antioxidants: Relationship in green cells. Physiol. Plant. 100, 224233.

Aly, M.H.A., Abd El-All, Azza and Mostafa, Soha (2008) Enhancement of sugar beet seed germination, plant growth, performance and biochemical compounds as contributed by extra cellular products. J. Agric. Sci., Mansoura Univ. 33(12), 8429-8448.

Apel, K. and Hirt, H. (2004) Reactive oxygen species: Metabolism, oxidative stress, and signal transduction. Annu. Rev. Plant Biol. 55, 373-399.

Ashraf, M. (2004) Some important physiological selection criteria for salt tolerance in plants. Flora, 199, 361-376.

Ashraf, M. (2009) Biotechnological approach of improving plant salt tolerance using antioxidants as markers. Biotech. Adv. 27, 84-93.

Ashraf, M., Athar, H.R., Harris, P.J.C. and Kwon, T.R. (2008) Some prospective strategies for improving crop salt tolerance. Adv. Agron. 97, 45-110.

AOAC. (1995) In: "Official Methods of Analysis". 16 ed. Association of Official Analytical Chemists, Arlington, Virginia.
Bates, L.S., Waldren, R.P. and Tear, I.D. (1973) Rapid determination of free proline for water stress studies. Plant Soil, 39, 205-207.

Bradford, M.M. (1976) A rapid and sensitive method for the quantitation of microgram quantities of protein utilizing the principle of protein-dye binding. Ann. Biochem. 72, 248-254.

Bray, G.A. (1960) A simple efficient liquid scintillator for counting aqueous solutions in a liquid scintillation counter. Anal. Biochem.1, 276-285.

Caplan, A.B., Dekeyser, C.R. and Van Montagu, M. (1990) Salinity and drought stress in rice. In: "The Impact of Biotechnology in Agriculture", Sangwan, R.S. and Sangwan-Norrel, B. (Ed.), pp. 391-402. Kluwer Academic Publishers The Netherlands.

Chance, B. and Maehly, A.C. (1995) Assays of catalases and peroxidases. Methods Enzymol. 2, 764-775.

Chen, C. and Dickman, M.B. (2005) Proline suppresses apoptosis in the fungal pathogen Colletotrichum trifolii. PNAS, 102, 3459-3464.

Chen, P., Yan, K., Shao, H. and Zhao, S. (2013) Physiological mechanisms for high salt tolerance in wild Soybean (Glycine soja) from Yellow River delta, China: Photosynthesis, osmotic regulation, ion flux and antioxidant capacity. PLOS ONE, 8, e83227.

Chen, Z., Cuin, T.A., Zhou, M., Twomey, A., Naidu, B.P. and Shabala, S. (2007) Compatible solute accumulation and stress-mitigating effects in barley genotypes contrasting in their salt tolerance. J. Exp. Bot. 58, 4245-4255.

Dorudi, M.S. and Siadat, H. (1999) The effect of irrigation salinity, potassium sulfate and urea on yield and nutrients concentration in wheat. Agric. Sci. J. of Iran. (Wheat special issue), 12, 187-196. (Persian).

El-Defan, T.A.A., El-Kholi, H.M.A., Rifaat, M.G.M. and Allah, A.E.A. (1999) Effect of soil and foliar application of potassium on yield and mineral content of wheat grains grown in sandy soils. Egy. J. Agric Res. 77(2), 513-522.

Garg, B.K. and Gupta, I.C. (1997) "Saline Wastelands Environment and Plant Growth". Jodhpur: Scientific Publishers. 
Garg, B.K., Vyas, S.P., Kathju, S., Lahiri, A.N., Mali, P.C. and Sharma, P.C. (1993) Salinity-fertility interaction on growth, mineral composition and nitrogen metabolism of Indian mustard. J. Plant Nutrition. 16, 1637-1650.

Grattan, S.R. and Grieve, C.M. (1992) Mineral element acquisition and growth response of plants grown in saline environments. Agric. Ecosystems. Environ. 38, 275-300.

Guzmán-Murillo, M.A., Ascencio, F. and LarrinagaMayoral, J.A. (2013) Germination and ROS detoxification in bell pepper (Capsicum annuum L.) under $\mathrm{NaCl}$ stress and treatment with microalgae extracts. Protoplasma, 250(1), 33-42.

Hegde, D.M., Dwivedi, B.S. and Babu, S.N.S. (1999) Biofertilizers for cereal production in India - A review. Ind. J. Aric. Sci. 69, 73-83.

Heidari, M. and Jamshid, P. (2010) Interaction between salinity and potassium on grain yield, carbohydrate content and nutrient uptake in pearl millet. ARPNJ. Agric. Bio. Sci. 5(6), 39-46.

Hemida, K.A., Refaat, M. and Wael, M. (2015) Enhance salt stress tolerance in wheat (Triticum aestivum L.) plant using exogenous $\beta$-carotene or algal extract. Enhance salt stress tolerance in wheat (Triticum aestivum L.) plant using exogenous $\beta$-carotene or algal extract. I.J.B.S. 2, 26-32.

Hoagland, D.R. and Arnon, D.I. (1950) The water culture method for growing plants without soil. Calif. Agr. Expt. Sta. Circ. 347, 1-32.

Inskeep, W.P. and Bloom, P.R. (1985) Extinction coefficients of chlorophyll $\mathrm{a}$ and $\mathrm{b}$ in $\mathrm{N}$, Ndimethylformamide and $80 \%$ acetone. Plant Physiol. 77, 483-485.

Jain, M., Mathur, G., Koul, S. and Sarin, N.B. (2001) Ameliorative effects of proline on salt stress induced lipid peroxidation in cell lines of groundnut (Arachis hypogea L.). Plant Cell Rep. 20, 463-468.

Joseph, B. and Jini, D. (2010) Insight into the role of antioxidant enzymes for salt tolerance in plants. Int. J. Bot. 6, 456-464.

Karthikeyan, N., Prasanna, R., Nain, L. and Kaushik, B.D. (2007) Evaluating the potential of plant growth promoting cyanobacteria as inoculants for wheat. Eur. J. Soil Biol. 43(1), 23-30.

Kavitha, P.G., Miller, A.J., Mathew, M.K. and Maathuis, F.J.M. (2012) Rice cultivars with differing salt tolerance contain similar cation channels in their root cells. J. Exp. Bot. 63, 3289-3296.

Kaye, Y., Golani, Y., Singer, Y., Leshem, Y., Cohen, G., Ercetin, M., Gillaspy, G., and Levine, A. (2011) Inositol polyphosphate 5-phosphatase7 regulates the production of reactive oxygen species and salt tolerance in Arabidopsis. Plant Physiol. 157(1), 229-241.

Kemka, H.O., Rebecca, A.A. and Gideon, O.A. (2007) Influence of temperature and $\mathrm{pH}$ bioresource and protein biosynthesis in putative Spirulina sp. Bioresource Technol. 98, 2207-2211.

Khan, A.A., Rao, S.A. and McNeilly, T. (2003) Assessment of salinity tolerance based upon seedling root growth response function in maize (Zea mays L.). Euphetica, 131, 81-89.

Ludlow, M.M. and Muchow, R.C. (1990) A critical evaluation of traits for improving crop yields in water-limited environments. Adv. Agron. 43, 107153.

Mahboobeh, R. and Akbar, E.A. (2013) Effect of salinity on growth, chlorophyll, carbohydrate and protein contents of transgenic Nicotiana plumbaginifolia over expressing P5CS gene. J. Environ. Res. Management, 4(1), 0163-0170.

Mahmoud, A.A., Mostafa, Soha S.M., Abd El-All, Azza A.M. and Hegazi, A.Z. (2007) Effect of cyanobacterial inoculation in presence of organic and inorganic amendments on carrot yield and sandy soil properties under drip irrigation regime. Egypt. J. Appl. Sci. 22(12B), 716-733.

Marschner, H. (1986) "Mineral Nutrition in Higher Plants". Academic Press, London.

Merril, C.R. (1990) Gel staining techniques. In: "Methods in Enzymology", Mp. Deutscher (Ed.), pp. 477-488. Vol. 182, Academic Press, New York.

Mosulishvili, L.M., Kirkesali, E.I. and Belokobylsky, A.I. (2002) Experimental substantiation of the possibility of developing selenium- and iodinecontaining pharmaceuticals based on bluegreen algae Spirulina platensis. J. Pharma. Biomed. 
Analysis, 30(1), 87-97.

Moussa, H.R. (2008) Gamma irradiation effects on antioxidant enzymes and G6PDH activities in Vicia faba plants. J. New Seeds, 9(1), 89-99.

Moussa , H.R. and Hassen, A.M. (2017) Selenium affects physiological responses of Phaseolus vulgaris in response to salt level. Int. J. Veget. Sci. $1-19$.

Moussa, H.R., Abd El-Fattah, M. and Mohamed, H. (2016) Growth enhancers to mitigate salinity stress in Vicia faba. Intl. J. Veg. Sci. 22(3), 243-250.

Navrot, N., Rouhier, N., Gelhaye, E. and Jacquot, J.P. (2007) Reactive oxygen species generation and antioxidant systems in plant mitochondria. Physiol. Plant, 129(1), 185-195.

Overlach, S., Diekmann, W. and Raschke, K. (1993) Phosphate translocator of isolated guard-cell chloroplasts from Pisum sativum L. transport glucose-6-phosphate. Plant. Physiol. 101, 12011207.

Prasanthi Kumara, R. and Vishnuvardhan, Z. (2015) Effect of salinity on growth, protein and antioxidant enzymes in three kodo millet (Paspalum scrobiculatum) germplasm. Int. J. Curr. Microbiol. App. Sci. 4(6), 475-483.

Priyadarshani, I. and Rath, B. (2012) Commercial and industrial applications of micro algae - A review. $J$. Algal Biomass Utln. 3(4), 89-100.

Prokopy, W.R. (1995) Phosphorus in acetic acid extracts. Quickchem Method 12-115-01-1-1- B. Lachat Instruments, Milwaukee, WI.

Raza, S.H., Habib, R.A., Ashraf, M. and Hameed, A. (2007) Glycine betaine induced modulation of antioxidant enzymes activities and ion accumulation in two wheat cultivar differing in salt tolerance. Enviro. Experim. Bot. 3, 368-376.

Sadasivam, S. and Manickam, A. (2008) "Biochemical Methods", $3^{\text {rd }}$ ed. New Age International (P) Ltd. Publishers, New Delhi.
Sànchez, M.C., Castillo, B. Rozo and Rodriguez, I. ( 2003) (Spirulina Arthrospira): An edible microorganism. A review. Universitas Scientiarum, $\mathbf{8}, 1$. Bogotà, Colombia.

Shannon, M.C. (1998) Adaptation of plants to salinity. Adv. Agron. 60, 75-119.

Singh, P.K. and Bisoyi, R.N. (1989) Blue-green algae in rice fields. Phykos. 28, 181-195.

Talei, D., Abdul Kadir, M., Yusop, M.K., Valdiani, A. and Abdullah, M.P. (2012) Salinity effects on macro and micronutrients uptake in medicinal plant King of Bitters (Andrographis paniculata Nees.). Plant Omics Journal, 5(3), 271-278.

Tester, M. and Davenport, R. (2003) $\mathrm{Na}^{+}$tolerance and $\mathrm{Na}^{+}$transport in higher plants. Ann. Bot. 91, 503-507.

Thomas, R.L., Jen, J.J. and Morr, C.V. (1981) Changes in soluble and bound peroxidase, IAA oxidase during tomato fruit development. J. Food Sci. 47, 158-161.

Ullah, S.M., Gerzabek, M.H. and Sojal, G. (1994) Effect of seawater and soil salinity on ion uptake, yield and quality of tomato (fruit). Bodenkultur, 45(3), 227-237.

Vaishampayan, A., Sinha, R.P., Hader, D.P., Dey, T., Gupta, A.K., Bhan, U. and Rao, A.L. (2001) Cyanobacterial biofertilizers in rice agriculture. Botanical Review, 67(4), 453-516.

Vendan, R.T. and Rajeshwari, T. (1998) Spirulina the wonder algae. Kisan World. 25.

Zheng, J. and Gao, Y. (2008) Growth and calcium bioaccumulation of Spirulina in photoheterotrophic cultures. J. Biotec.136, 558-576.

Received 14/5/2018; accepted 12/10/2018) 
الآثار الفسيولوجية لطحلب الإسبيرولبنا بلاتبنبسيس في نبات الفول المُّرَّه للإجهاد

المثحى

إيمان السيد سليم

قسم النبات ـ كلية العلوم - جامعة الزقازيق ـ الزقازيق - مصر

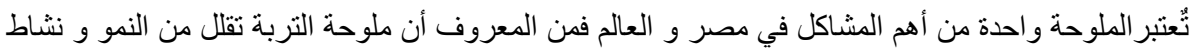

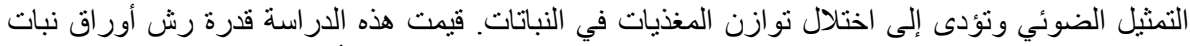

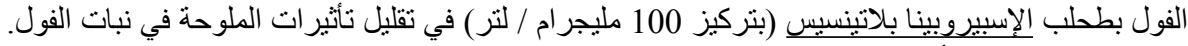

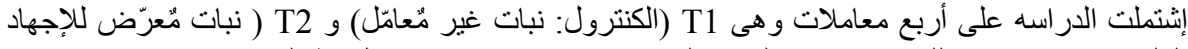

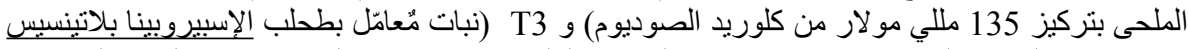

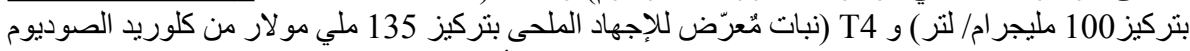

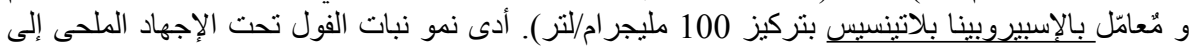

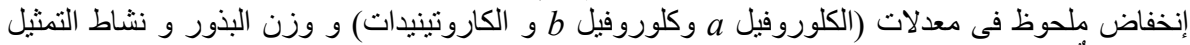



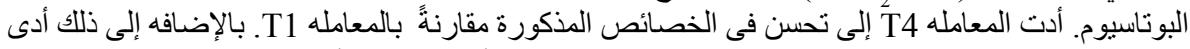

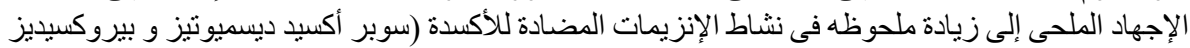



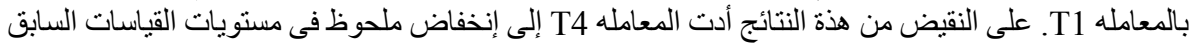

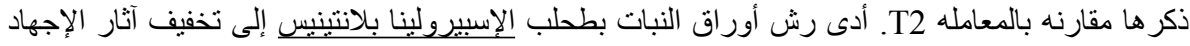

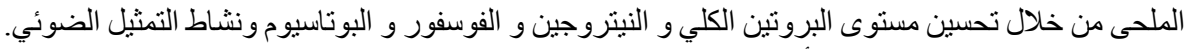

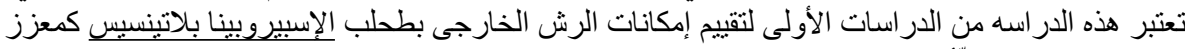

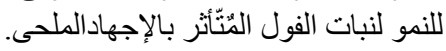

